\title{
PERANAN MANAGEMENT PUBLIC RELATIONS DALAM MEMPERTAHANKAN CITRA PERUSAHAAN JASA PERHOTELAN: STUDI KUALITATIF PADA RE-OPENING HOTEL MANDARIN ORIENTAL, JAKARTA
}

\author{
Aryanti Puspokusumo \\ Jurusan Manajemen, Fakultas Ekonomi dan Bisnis, Bina Nusantara University \\ Jln. K.H. Syahdan No. 9, Kemanggisan, Palmerah, Jakarta Barat 11480
}

\begin{abstract}
The purpose of this research is to identify implementation of image building and public relations that has been done by MOJKT in HI roundabout in Jakarta that took part in hotel service. Theories that used are communication management theory, PR theory, and image theory. Those theories will be connected with the analysis result in the field. The research method used is qualitative descriptive using analysis method of 6 stages of Public Relations Plan.
\end{abstract}

Keywords: public, public relations, image, hotel

\begin{abstract}
ABSTRAK
Tujuan dilaksanakannya penelitian ini adalah untuk mengetahui pelaksanaan peran Image Building dan Public Relations yang dilakukan oleh MOJKT di kawasan Bunderan HI Jakarta yang bergerak di dalam bidang pelayanan jasa perhotelan. Teori-teori yang digunakan adalah teori management komunikasi, teori Public Relations dan teori citra. Teori yang digunakan oleh penulis kemudian dikaitkan dengan hasil analisa yang didapatkan di lapangan. Metode penelitian yang digunakan adalah deskriptif kualitatif dengan menggunakan metode analisa 6 stages of Public Relations Plan.
\end{abstract}

Kata kunci: masyarakat, public relations, pencitraan, hotel 


\section{PENDAHULUAN}

\section{Latar Belakang Masalah}

Hotel adalah perusahaan jasa yang menyediakan tempat atau sarana istirahat untuk sementara waktu bagi tamunya serta fasilitas pendukung lainnya. Dalam Surat Keputusan Menparpostel No. KM 37/PW.340/MPPT-86, tentang Peraturan Usaha dan Penggolongan Hotel, Bab I Pasal 1 Ayat (b) dalam SK (Surat Keputusan) tersebut menyebutkan bahwa hotel adalah suatu jenis akomodasi yang mempergunakan sebagian atau seluruh bangunan untuk menyediakan jasa penginapan, makanan dan minuman serta jasa penunjang lainnya bagi umum yang dikelola secara komersial. Dari pengertian tersebut maka hotel berbeda dengan penginapan atau losmen, karena pengertian penginapan atau losmen, adalah suatu usaha komersial yang menggunakan seluruh atau sebagian dari suatu bangunan yang khusus disediakan bagi setiap orang untuk memperoleh pelayanan sewa kamar untuk menginap. Jadi perbedaannya adalah penginapan atau losmen tidak menyediakan fasilitas penunjang seperti makanan atau minuman.

Di Jakarta sendiri saat ini memang banyak bermunculan hotel berbintang lima untuk mendukung aktifitas bisnis. Setiap hotel biasanya memiliki ciri khasnya masing-masing sesuai dengan target yang dituju. Salah satunya adalah Hotel Mandarin Oriental (MOJKT), Jakarta. sebagai salah satu jenis City Hotel karena berlokasi di pusat kota. Kebanyakan tamunya adalah orang asing yang sedang singgah di Jakarta untuk melakukan bisnis walaupun ada juga dari wisatawan tersebut yang datang berkunjung untuk melakukan perjalanan wisata. MOJKT sendiri berada di bawah manajemen Mandarin Oriental Hotel Group (MOHG) yang merupakan sebuah jaringan bisnis perhotelan bertaraf Internasional dan terpusat di Hongkong. Tersebar di 25 negara di empat benua, yaitu Asia 17 hotel, Amerika 14 hotel dan Eropa serta Afrika Utara 10 hotel, MOHG memiliki lebih dari 10.000 kamar di seluruh dunia yang berperingkat bintang lima. MOJKT terletak di lokasi yang merupakan pusat bisnis dan kawasan diplomatik ibukota Jakarta karena terletak tepat di sebelah Kedutaan Jerman dan berhadapan dengan Hotel Indonesia Kempinski, Hotel Grand Hyatt serta pusat perbelanjaan Plaza Indonesia, Ex dan Grand Indonesia. Lokasinya \pm 45 menit dari Bandara Internasional Soekarno Hatta yang menandakan bahwa hotel ini dapat dengan mudah dijangkau oleh masyarakat maupun tamu.

Dikarenakan lokasinya yang strategis maka MOJKT ini dikelilingi oleh beberapa hotel kompetitor seperti Hotel Indonesia Kempinski, Hotel Grand Hyatt dan Hotel Nikko Jakarta. Walaupun ketiganya mempunyai target yang sama tetapi mereka selalu tetap berusaha untuk bersaing secara sehat. Namun MOJKT sendiri sadar harus mempunyai perbedaan dengan kompetitor yang ada di sekelilingnya. Oleh sebab itu mereka ingin salah satu perbedaan itu adalah pada pelayanan yang diberikan. Pelatihan yang diberikan kepada para karyawannya diharapkan memberikan hasil sesuai dengan tujuan mereka yaitu memberikan pelayanan yang terbaik. Setelah 30 tahun beroperasi maka pada tahun 2007 sampai tahun 2009 MOJKTmemutuskan untuk melakukan renovasi pada bangunan hotel. Dengan pertimbangan bahwa kondisi hotel yang sudah cukup tua maka seluruh design serta perlengkapan dan aksesoris hotel pun diganti. Penggantian konsep ini juga diikuti oleh fasilitas lainnya seperti restoran, bar, cake shop, ruang meeting, banquet, fitness centre, treatments rooms and pools.

MOJKT tersebut dibuka kembali mulai tanggal 1 Oktober 2009 dan diresmikan oleh Ibu Mari Elka Pangestu yang saat ini menjabat sebagai Menteri Perdagangan Indonesia. Dengan mengusung konsep design baru yang mewah memiliki 272 kamar. Setelah adanya renovasi yang dilakukan oleh MOJKT diharapkan agar tamu dapat tetap merasakan citra sebagai hotel bintang lima yang berkelas. Karena tujuan awal dari renovasi ini adalah memperbarui design ruangan dimana sudah kurang lebih 29 tahun MOJKT berdiri. Dari penjelasan diatas, penulis melihat bahwa peranan Public Relations sangat penting untuk membentuk citra positif bagi MOJKT sehingga dapat bersaing dengan Hotel di sekelilingnya. Lalu setelah dilaksanakannya renovasi seberapa besar dampaknya terhadap citra dari hotel tersebut di mata masyarakat atau tamu. 


\section{Tujuan Penelitian}

Adapun tujuan penelitian ini adalah (1) untuk mengetahui peran Public Relations dalam membangun citra Hotel Mandarin Oriental setelah re-opening; (2) untuk mengetahui kegiatankegiatan promosi apa saja yang dilakukan oleh Public Relations untuk mendukung re-opening Hotel Mandarin Oriental; (3) untuk mengetahui hambatan apa saja yang ditemui selama kegiatan promosi Public Relations untuk mendukung re-opening Hotel Mandarin Oriental dan upaya untuk mengatasi hambatan tersebut.

\section{Kerangka Teoritis}

\section{Pengertian Komunikasi}

Komunikasi dalam kehidupan manusia merupakan salah satu kebutuhan yang sangat penting. Hal tersebut disebabkan manusia sebagai makhluk sosial yang membutuhkan interaksi dengan sesamanya. Baik itu untuk menyampaikan informasi, perasaan, pikiran, pendapat ataupun sikapnya. Komunikasi atau communication berasal dari bahasa Latin, communicatio yang berarti pertukaran. Kata sifatnya adalah communis, yang berarti umum atau bersama-sama.

Menurut Trenholm \& Jensen dalam Wiryanto (2004), definisi dari komunikasi adalah suatu proses dimana sumber mentransmisikan pesan kepada penerima melalui beragam saluran. Hoveland dalam Wiryanto (2004) mendefinisikan komunikasi sebagai proses dimana individu mentransmisikan stimulus untuk mengubah prilaku individu yang lain. Ada berbagai macam definisi komunikasi yang dihasilkan oleh para ahli dan masing-masing mempunyai pendapat yang berbeda-beda. Namun dari beberapa definisi di atas dapat penulis simpulkan bahwa komunikasi adalah suatu proses terjadinya pertukaran informasi untuk menyampaikan pesan antara dua orang atau lebih sehingga menimbulkan pengertian yang sama.

\section{Fungsi dan Tujuan Komunikasi}

Menurut Effendy (1999) fungsi dari komunikasi adalah: menyampaikan pesan (to inform); mendidik (to educate); menghibur (to entertain); mempengaruhi (to influence). Menurut Effendy (1999) tujuan dari komunikasi yaitu: perubahan sikap (attitude change), perubahan pendapat (opinion change), perubahan perilaku (behavior change), perubahan sosial (social change).

\section{Model Komunikasi Laswell}

Salah satu model komunikasi datang dari Laswell dalam Mulyana (2007) yang menyebutkan bahwa proses komunikasi, yaitu: who says what in which channel to whom with what effect. Model komunikasi ini dikemukakan oleh Laswell pada 1948. Maka dapat disimpulkan bahwa proses komunikasi adalah proses penyampaian pesan dari komunikator melalui media kepada komunikannya sehingga menimbulkan timbal balik.

\section{Hambatan Komunikasi}

Hambatan komunikasi oleh Kreitner dalam Ruslan (2006), dibagi menjadi 4 (empat) macam, yaitu: hambatan dalam proses penyampaian (process barriers), hambatan secara fisik (physical barriers), hambatan semantik (semantik barriers), hambatan psiko sosial (phychological barriers). Hambatan-hambatan komunikasi tersebut dapat menyebabkan gagalnya sebuah komunikasi yaitu menciptakan pengertian yang sama. Untuk meminimalisir terjadinya hal tersebut maka komunikator harus mengenali lebih dalam tentang orang atau kelompok yang hendak diajak berkomunikasi. 


\section{Pengertian Public Relations}

Menurut British Institute of Public Relations dalam (Jefkins \& Yadin, 2004) definisi Public Relations adalah keseluruhan upaya yang dilakukan secara terencana dan berkesinambungan dalam tangka menciptakan dan memelihara niat baik (goodwill) dan saling pengertian antara suatu organisasi dengan segenap khalayaknya. Sedangkan menurut Jefkins \& Yadin (2004), Public Relations didefinisikan sebagai semua bentuk komunikasi yang terencana, antara satu organisasi dengan semua khalayaknya dalam rangka mencapai tujuan-tujuan spesifik yang berlandaskan pada saling pengertian.

Pernyataan Meksiko (the mexican statement) dalam (Jefkins \& Yadin, 2004) menghasilkan definisi praktik Public Relations yaitu sebuah seni sekaligus ilmu sosial yang menganalisis berbagai kecenderungan, memperkirakan setiap kemungkinan konsekuensinya, memberi masukan dan saransaran kepada para pemimpin organisasi, serta menerapkan program-program tindakan yang terencana untuk melayani kebutuhan organisasi dan kepentingan khalayaknya.

\section{Peran Public Relations}

Menurut Dozier dalam (Kusumastuti, 2002) peran Public Relations dapat dibagi menjadi 2 (dua), yakni peranan managerial (communication manager role) dan peranan teknis (communication technical role). Peranan manajerial dikenal dengan peranan di tingkat messo (manajemen) dapat diuraikan menjadi 3 (tiga) peranan, yakni expert preciber communication, problem solving process facilitator, dan communication facilitator. Sehingga bila dijelaskan lebih jauh terdapat 4 (empat) peranan, meliputi: (1) expert preciber communication; petugas PR dianggap sebagai orang yang ahli. Dia menasihati pimpinan perusahaan/organisasi. Hubungan mereka diibaratkan seperti hubungan dokter dan pasien; (2) problem solving process facilitator; yakni peranan sebagai fasilitator dalam proses pemecahan masalah. Pada peranan ini petugas humas melibatkan diri atau dilibatkan dalam setiap manajemen (krisis). Dia menjadi anggota tim, bahkan bila memungkinkan menjadi leader dalam penanganan krisis manajemen; (3) communication facilitator: peranan petugas humas sebagai fasilitator komunikasi perusahaan/organisasi dengan publik. Baik dengan publik eksternal maupun internal. Istilah yang paling umum adalah sebagai jembatan komunikasi antara publik dengan perusahaan. Sebagai media atau penengah bila terjadi miskomunikasi; (4) technician communication: di sini petugas humas dianggap sebagai pelaksana teknis komunikasi. Dia menyediakan layanan di bidang teknis, sementara kebijakan dan keputusan teknik komunikasi mana yang akan digunakan bukan merupakan keputusan petugas humas, melainkan keputusan manajemen dan petugas humas yang melaksanakannya.

\section{Fungsi dan Tujuan Public Relations}

Fungsi Public Relations menurut Bertrand R. Canfield dalam (Ruslan,1999) yaitu: pengabdian kepada kepentingan umum, memelihara komunikasi yang baik, menitikberatkan moral dan perilaku yang baik. Tujuan utama PR adalah membantu tercapainya tujuan organisasi (Rumanti, 2002) dan untuk mencapai tujuan tersebut maka seorang Public Relations maka dapat melaksanakan hal-hal seperti: (1) persuasi dengan pengertian mengubah sikap, tingkah laku publik terhadap organisasi demi keuntungan kedua belah pihak; (2) usaha untuk mengintegrasikan sikap dan perbuatan organisasi dengan sikap atau perbuatan publik atau sebaliknya; (3) secara terus menerus menciptakan dan memperbaiki relasi dengan publik khusus, potensial, umum, pribadi maupun kelompok, merupakan kelanjutan kehidupan organisasi. Hal ini merupakan tugas vital, harus ditingkatkan secara lokal, nasional maupun internasional. Inilah tugas penting dalam manajemen modern dewasa ini; (4) semua kegiatan supaya berhasil baik perlu perencanaan yang tepat. Dalam PR, penelitian sangat mendasar, merupakan instrumen dengan tujuan untuk menemukan perspektif yang strategis. 
Tujuan-tujuan tersebut di atas harus dipelihara dengan baik agar dapat membina hubungan baik dengan publiknya sehingga tujuan perusahaan untuk menciptakan citra positif bagi perusahaan dapat tercapai.

\section{Pengertian Citra}

Menurut Ardianto \& Soemirat (2003), citra adalah kesan yang diperoleh seseorang berdasarkan pengetahuan dan pengertiannya tentang fakta-fakta atau kenyataan. Untuk mengetahui citra seseorang terhadap suatu obyek dapat diketahui dari sikapnya terhadap obyek tersebut. Pengertian citra menurut Kamus Besar Bahasa Indonesia dalam Ardianto \& Soemirat (2003) adalah (1) kata benda: gambar, rupa, gambaran; (2) gambaran yang dimiliki orang banyak mengenai pribadi, perusahaan, organisasi atau produk; (3) kesan mental atau bayangan visual yang ditimbulkan oleh sebuah kata, frase atau kalimat, dan merupakan unsur dasar yang khas dalam karya prosa atau puisi. Citra yang positif bagi sebuah perusahaan sangat penting karena jika citra tersebut sudah didapatkan maka masyarakat akan menerima dengan baik produk atau jasa yang dihasilkan oleh perusahaan tersebut dan dalam hal ini fungsi seorang Public Relations sangat diperlukan.

\section{Jenis-Jenis Citra}

Menurut Jefkins dalam Ardianto \& Soemirat (2003), jenis-jenis citra ada 4 dapat dijabarkan sebagai berikut, yaitu (1) the mirror image (cerminan citra), yaitu bagaimana dugaan (citra) manajemen terhadap publik eksternal dalam melihat perusahaannya; (2) the current image (citra masih hangat), yaitu citra yang terdapat pada publik eksternal, yang berdasarkan pengalaman atau menyangkut miskinnya informasi dan pemahaman publik ekternal. Citra ini bisa saja bertentangan dengan mirror image; (3) the wish image (citra yang diingiinkan), yaitu manajemen menginginkan pencapaian prestasi tertentu. Citra ini diaplikasikan untuk sesuatu yang baru sebelum publik eksternal memperoleh informasi secara lengkap; (4) the multiple image (citra yang berlapis), yaitu sejumlah individu, kantor cabang atau perwakilan perusahaan lainnya dapat membentuk citra tertentu yang belum tentu sesuai dengan keseragaman citra seluruh organisasi atau perusahaan.

\section{Perusahaan Jasa/ Pengertian Jasa}

Pengertian arti kata jasa (service) menurut Yoeti (2004) adalah suatu produk yang tidak nyata (intangible) dari hasil kegiatan timbal balik antara pemberi jasa (producer) dan penerima jasa (customer) melalui suatu atau beberapa aktivitas untuk memenuhi kebutuhan pelanggan. Sedangkan menurut Kotler dalam Tjiptono (1996), jasa adalah setiap tindakan atau perbuatan yang dapat ditawarkan oleh suatu pihak kepada pihak lain, yang pada dasarnya bersifat intangible (tidak berwujud fisik ) dan tidak menghasilkan kepemilikan sesuatu. Produksi jasa bisa berhubungan dengan produk fisik maupun tidak. Industri jasa adalah industri yang perlu memperhatikan pelayanan karena hasil produksinya tidak bisa dilihat secara nyata. Proses produksinya berlangsung bersamaan dengan terjadinya pelayanan pada konsumen sehingga penilaian kepuasan pelanggan terjadinya pada saat itu juga dan tidak bisa diulang.

\section{Karakteristik Jasa}

Menurut Tjiptono (1996), ada 4 (empat) karakterisitik pokok pada jasa yang membedakan dari barang, yaitu: (1) intagibility: jasa berbeda dengan barang. Jika barang merupakan suatu objek, alat, atau benda, maka jasa adalah suatu perbuatan, kinerja (performance), atau usaha. Bila barang dapat dimiliki, maka jasa hanya dapat dikonsumsi tetapi tidak dapat dimiliki. Meskipun sebagian besar jasa dapat berkaitan dan didukung oleh produk fisik misalnya mobil dalam jasa transportasi, esensi dari apa yang dibeli pelanggan adalah performance yang diberikan oleh suatu pihak kepada pihak lainnya. (2) Inseparibility: barang biasanya diproduksi, kemudian dijual, lalu dikonsumsi. Sedangkan jasa biasanya dijual terlebih dahulu, baru kemudian diproduksi dan dikonsumsi secara bersamaan. (3) Variability: 
jasa bersifat sangat variabel karena merupakan nonstandarized output, artinya sangat banyak variasi bentuk, kualitas dan jenis, tergantung pada siapa, kapan dan dimana jasa tersebut dihasilkan. (4) Perishability: jasa merupakan komoditas tidak tahan lama dan tidak dapat disimpan. Kursi pesawat yang kosong, kamar hotel yang tidak dihuni, atau jam tertentu tanpa pasien di tempat praktik dokter gigi akan berlalu/hilang begitu saja karena tidak dapat disimpan. Dengan demikian bila suatu jasa tidak digunakan, maka jasa tersebut akan berlalu begitu saja.

\section{Pengertian Hotel}

Pengertian hotel menurut Hotel Proprietors Act 1956 dalam (Sulastiyono, 2008:4) hotel adalah suatu perusahaan yang dikelola oleh pemiliknya dengan menyediakan makanan, minuman dan fasilitas kamar untuk tidur kepada orang-orang yang sedang melakukan perjalanan dan mampu membayar dengan jumlah yang wajar sesuai dengan pelayanan yang diterima tanpa adanya perjanjian khusus. Sedangkan Grolier Electronics Publishing Inc,1995 menyebutkan bahwa hotel adalah usaha komersial yang menyediakan tempat menginap, makanan, dan pelayanan - pelayanan lain untuk umum.

\section{Klasifikasi dan Jenis Hotel}

Departemen Pariwisata, Pos dan Telekomunikasi melalui Direktorat Jenderal Pariwisata mengeluarkan suatu peraturan usaha dan penggolongan hotel (SK No. KM 37/PW.304/MPPT-86) yang menggolongkan hotel yang disusun dari hotel berbintang 1 sampai dengan yang tertinggi adalah hotel bintang 5 (Sulastiyono, 2008). Secara garis besar kriteria yang digunakan untuk penggolongan hotel tersebut didasarkan pada unsur-unsur persyaratan, yaitu fisik, operational/manajemen, pelayanan. Kriteria fisik, yaitu: (1) besar atau kecilnya hotel atau banyak/sedikitnya jumlah kamar tamu; (2) hotel kecil, hotel dengan 25 kamar atau kurang; (3) hotel sedang, hotel yang memiliki lebih dari 25 dan kurang dari 100 kamar; (4) hotel menengah, hotel dengan jumlah kamar lebih dari 100 dan kurang dari 300 kamar; (5) hotel besar, adalah hotel yang memiliki lebih dari 300 kamar; (6) kualitas, lokasi dan lingkugan bangunan; (7) fasilitas yang tersedia untuk tamu, seperti ruang penerima tamu, dapur, toilet, dan telepon umum; (8) perlengkapan yang tersedia, baik bagi karyawan, tamu maupun bagi pengelola hotel. Peralatan yang dimilki oleh setiap departemen/bagian, baik yang digunakan untuk keperluan pelayanan tamu, ataupun untuk keperluan pelaksanaan kerja karyawan; (9) kualitas bangunan, yang dimaksud adalah kualitas bahan-bahan bangunan yang dipergunakan, seperti kualitas lantai, dinding, termasuk juga tingkat kekedapan terhadap api, kekedapan terhadap suara yang datang dari luar ataupun dari dalam hotel; (10) tata letak ruang, dan ukuran ruang.

Kriteria operasional atau manajemen yaitu: (1) struktur organisasi dengan uraian tugas dan manual kerja secara tertulis bagi masing-masing jabatan yang tercantum dalam organisasi; (2) tenaga kerja, spesialisasi dan tingkat pendidikan karyawan disesuaikan dengan persyaratan peraturan penggolongan hotel. Selain itu, kriteria pelayanan yaitu: (1) keramahtamahan, sopan dan mengenakan pakaian seragam hotel; (2) pelayanan diberikan dengan mengacu pada kebutuhan-kebutuhan dan keinginan-keinginan tamu; (3) untuk hotel bintang 4 dan 5, pelayanan dibuka 24 jam.

Dijelaskan oleh United States lodging industry dalam (Sulastiyono, 2008) hotel terbagi menjadi 3 (tiga) jenis, yaitu: (1) transient hotel, adalah hotel yang letak/lokasinya di tengah kota dengan jenis tamu yang menginap sebagian besar adalah untuk urusan bisnis dan turis; (2) residential hotel, adalah hotel yang pada dasarnya merupakan rumah-rumah yang berbentuk apartemen dengan kamar-kamarnya, dan disewakan secara bulanan atau tahunan. Residential Hotel juga menyediakan kemudahan-kemudahan seperti layaknya hotel, seperti restoran, pelayanan makanan yang diantar ke kamar, dan pelayanan kebersihan kamar; (3) resort hotel, adalah hotel yang pada umumnya berlokasi di tempat-tempat wisata, dan menyediakan tempat - tempat rekreasi dan juga ruang serta fasilitas konfrensi untuk tamu-tamunya. 


\section{Fasilitas Usaha Hotel}

Menurut keputusan Menparpostel fasilitas-fasiltas usaha sebuah hotel komersial meliputi: kamar tidur (kamar tamu); makanan dan minuman; pelayanan-pelayanan penunjang lainnya seperti: tempat-tempat rekreasi, fasilitas olahraga, fasilitas dobi (laundry), dan sebagainya (Sulastiyono, 2008). Seperti dimaksud dalam pengertian hotel bahwa hotel berbeda dengan penginapan atau losmen. Hotel komersial harus dilengkapi fasilitas penunjang lainnya sehingga pelayanan kepada tamunya dapat lebih memuaskan.

\section{METODOLOGI PENELITIAN} kualitatif.

Metode penelitian yang digunakan penulis pada thesis ini adalah penelitian deskriptif

\section{Tipe Penelitian}

Menurut Kountor (2005) penelitian deskriptif adalah jenis penelitian yang memberikan gambaran atau uraian atas keadaan sejelas mungkin tanpa ada perlakuan terhadap obyek yang diteliti. Sedangkan maksud dari penelitian kualitatif adalah penelitian yang bermaksud untuk memahami fenomena tentang apa yang dialami oleh subjek penelitian, misalnya perilaku, persepsi, motivasi dan tindakan yang menghasilkan data deskriptif berupa kata - kata dan bahasa yang untuk menggambarkan tentang karakteristik (ciri-ciri) individu, situasi, atau kelompok tertentu (Moleong, 2004).

\section{Narasumber}

Narasumber adalah seseorang yang mewakili perusahaan untuk dapat memberikan keterangan seputar objek penelitian yang sedang diteliti oleh penulis dan membantu memecahkan masalah yang terdapat di dalamnya. Dalam penelitiannya penulis mewawancarai beberapa narasumber untuk pengumpulan data, yaitu internal dan eksternal. Internal yaitu (1) communications manager: communication manager adalah sebutan lain dari Public Relations yang tugasnya membantu perusahaan dalam mencapai visi dan misi yang telah ditentukan sehingga menciptakan citra yang positif di mata masyarakat; (2) sales and marketing staff: sales and marketing staff adalah orang yang bertugas agar seluruh kapasitas hunian hotel yang tersedia dapat memenuhi target yang telah ditentukan.

Sementara itu, narasumber eksternal yang dipilih oleh penulis adalah narasumber yang pada saat penelitian penulis berlangsung sedang berada di tempat penelitiannya. Misalnya adalah tamu yang sedang menginap atau wakil dari perusahaan yang menyewa fasilitas tempat untuk rapat di Hotel Mandarin Oriental Jakarta. Dengan mewawancarai sumber eksternal ini diharapkan dapat memberikan bagaimana tanggapan para tamu terhadap objek penelitian penulis karena mereka adalah pengguna langsungnya.

\section{Metode Pengumpulan Data}

Menurut Hasan (2002) data primer adalah data yang diperoleh atau ditentukan langsung di lapangan oleh anggota yang melakukan penelitian atau yang bersangkutan yang memerlukannya. Salah satu untuk mendapatkan data primer adalah dengan melakukan wawancara. Wawancara adalah mendapatkan informasi dengan cara bertanya langsung kepada responden seperti diutarakan oleh Singarimbun \& Sofian (1989). Faktor-faktor yang mempengaruhi wawancara menurut Warwick \& Liningen dalam Singarimbun \& Sofian (1989) ada 4 (empat) faktor, yaitu: (1) pewawancara: karakterisrik sosial, ketrapilan mewawancarai, motivasi dan rasa aman; (2) responden: karakteristik 
sosial, kemampuan menangkap pertanyaan, kemampuan untuk menjawab pertanyaan; (3) isi kuesioner: peka untuk ditanyakan, sukar ditanyakan, tingkat minat, sumber kekhawatiran; (4) situasi wawancara: waktu, tempat, kehadiran orang ketiga, sikap masyarakat.

Ruslan (2004) mendefinisikan data sekunder sebagai data penelitian yang diperoleh secara tidak langsung melalui media perantara (dihasilkan pihak lain) atau digunakan oleh lembaga lainnya yang bukan merupakan pengolahnya, tetapi dapat dimanfaatkan untuk penelitian tertentu. Data sekunder biasanya data sudah tersedia contohnya seperti company profile.

\section{Metode Analisis Data}

Penelitian kualitatif adalah penelitian yang dilakukan lebih kepada pendapat seseorang tentang suatu objek penelitian. Oleh sebab itu hasil wawancara dari narasumber merupakan salah satu cara untuk mendapatkan data dan pertanyaan pun bersifat terbuka. Selain daripada itu buku-buku referensi dan company profile dapat juga membantu dalam mencari data. Analisis data adalah bagian dalam proses penelitian yang sangat penting, karena dengan analisa inilah data yang ada akan nampak manfaatnya terutama dalam memecahkan masalah penelitian dan mencapai tujuan akhir penelitian (Sugiyono, 2007). Penelitian yang dilakukan oleh penulis berlangsung pada bulan Oktober 2010Februari 2011 dengan berlokasi di Sales and Marketing Office Lantai 6 Hotel Mandarin Oriental Jakarta, Jalan MH. Thamrin PO Box 3392 Jakarta 10310.

\section{HASIL DAN PEMBAHASAN}

\section{Gambaran Umum Perusahaan}

Tujuan dari MOHG adalah untuk diakui secara luas sebagai kelompok hotel mewah yang terbaik di dunia dengan menyediakan kemewahan abad 21 dengan pesona timur di setiap hotelnya. Tujuan tersebut akan dicapai dengan berinvestasi pada fasilitas yang mempunyai prospek yang menjanjikan dan juga mempunyai orang-orang terbaik di dalam kelompok usaha ini sehingga meningkatkan laba dan nilai saham dalam jangka panjang. MOHG secara teratur menerima pengakuan dan penghargaan untuk pelayanan dan pengelolaan mutu yang terbaik Strategi kelompok usaha hotel ini adalah dengan membuka hotel-hotel yang saat ini sedang dikembangkan sambil terus mencari peluang-peluang baru yang potensial secara selektif untuk ekspansi di seluruh dunia.

Induk perusahaan MOHG, Mandarin Oriental Internatiional Limited, didirikan di Bermuda dan masuk bursa saham di London juga di Bermuda dan Singapura. MOHG yang beroperasi di Hong Kong mengelola kegiatan di setiap hotel-hotel yang berada di dalam kelompoknya. MOHG merupakan anggota kelompok Jardine Matheson. Mandarin Oriental Jakarta berdiri pada tahun 1978 dengan nama The Jakarta Mandarin. Diresmikan oleh Ibu Nelly Adam Malik, istri dari Bapak Adam Malik yang saat itu sebagai Wakil Presiden Republik Indonesia pada tanggal 9 September 1978. Baru pada tahun 1985 nama The Jakarta Mandarin berubah menjadi Mandarin Oriental Jakarta.

Konsep interior pada saat itu didesign oleh Palmer \& Turner dengan jumlah kamar 462 buah. Dalam waktu singkat MOJKT menjadi sebuah meeting point bagi kalangan bisnis Jakarta dan ekspatriat karena berada di lokasi yang strategis di pusat kota dan dikelilingi oleh beberapa kedutaan besar, gedung-gedung perkantoran serta pusat perbelanjaan mewah. Selain itu MOJKT juga menjadi pilihan para designer untuk memeragakan hasil karyanya seperti yang dilakukan oleh Josephine 'Obin' Komara atau tempat untuk mengadakan konser oleh Nick Mamahit selama 15 tahun. Setelah dibuka kembali pada Oktober 2009, MOJKT memiliki 272 buah kamar termasuk 56 Mandarin Room dan 6 suites yang terletak dari lantai 8 sampai lantai 26 dengan konsep design ruangan bertema kontemporer klasik hasil rancangan dari Lim, Teo \& Wilkes Design Firm asal Singapura. 


\section{Analisis dan Pembahasan}

Analisis yang digunakan oleh penulis adalah 6 stages Public Relations plan yaitu yang terdiri dari Situation Analysis, Objective(s), Publics, Media, Budget, and Evaluation. Melalui analisis ini diharapkan penulis dapat menganalisa situasi, mengetahui tujuan pengamatan, publik yang dituju, media apa saja yang digunakan, perencanaan keuangan dan mengevaluasi hasil pengamatan.

\section{Situation Analysis}

Pada tahun 1963 Hotel Mandarin Oriental Group pertama kali didirikan di Hongkong. Sedangkan Hotel Mandarin Oriental Jakarta berdiri sejak tahun 1978. Selama kurang lebih 30 tahun beroperasi tentunya hotel ini sudah sangat dikenal baik oleh publik secara umumnya dan khususnya tamu yang loyal menginap di hotel ini. Untuk hotel Mandarin Oriental Jakarta sendiri mereka memposisikan sebagai hotel bisnis, hal ini didukung juga oleh lokasi yang berada di pusat jantung ibukota dimana kegiatan bisnis terpusat di sekitarnya. Tamu yang menginap juga hampir seluruhnya untuk melakukan kegiatan bisnis di Jakarta, seperti dari Singapura dan Hongkong. Seperti yang dijelaskan oleh United State Lodging Industry dalam (Sulastiyono, 2008) hotel terbagi menjadi 3 (tiga) jenis yang salah satunya adalah transient hotel, yaitu hotel yang letak/lokasinya di tengah kota dengan jenis tamu yang menginap sebagian besar adalah untuk urusan bisnis dan turis. Pihak hotel khususnya dalam hal ini Communication Department selalu memantau masukan dari para tamu tentang hotel mereka melalui guest comments. Salah satu masukan yang mereka dapatkan dari para tamu adalah kondisi hotel yang sudah memerlukan perbaikan. Maka dari itu hal tersebut menjadi salah satu masukan mereka untuk melakukan renovasi pada tahun 2007 sampai 2009. Hotel Mandarin Oriental Jakarta mulai beroperasi kembali pada 1 Oktober 2009.

Untuk memberitahukan kepada publik bahwa hotel ini telah beroperasi kembali mereka melakukan berberapa macam kegiatan promosi. Beberapa macam kegiatan promosi tersebut seperti peresmian pembukaan hotel, Paket Hari Valentine, dan Perayaan Imlek yang diadakan pada saat bersamaan di bulan Februari 2011. Biasanya sebelum mengadakan event yang dimaksudkan untuk menarik perhatian para calon tamu dan mempertahankan citranya sebagai salah satu hotel ternama mereka menyesuaikan dengan hari-hari besar dan acara-acara penting yang sedang berlangsung di tengah masyarakat seperti: peresmian hotel yaitu pengguntingan pita dan paket hari Valentine yang ditawarkan pada bulan Februari 2011 di MOJKT. Pada event ini ditawarkan beberapa paket untuk pasangan seperti: (1) Ballroom for Two: Paket ini termasuk sebuah ruangan mewah seluas $590 \mathrm{~m}^{2}$ untuk dua orang yang dihias dengan nuansa laut dan dilengkapi bunga, meja makan dan lantai dansa serta layar lebar untuk menonton film pilihan tamu. Paket ini dijual dengan harga Rp. 10.000.000,00; (2) Do It Yourself with Love: Paket ini menawarkan sebuah keistimewaan karena tamu dapat memasak makan malam Valetine mereka langsung dengan chef dari MO Kitchen. Dijual dengan harga Rp. 6.000.000,00; (3) Cosy Valentine: Paket ini menawarkan sebuah nuansa nyaman seperti di rumah sendiri tanpa meninggalkan kesan mewah dan romantis, The Beaujolais. Ruangan yang disediakan dilengkapi dengan sofa, televisi layar datar, DVD, dan open bar. Paket yang juga termasuk menu makan malam spesial ini dijual dengan harga Rp. 5.000.000,00; (4) King and Queen: sebuah ruangan mewah, The Glass akan membawa tamu seperti Ratu dan Raja dalam melewatkan malam Valentine special mereka. Dekorasi ruangan yang unik dan makan malam special merupakan penawaran dari paket seharga Rp. 5.000.000,00 ini. Paket tersebut sudah termasuk penggunaan ruangan selama 6 jam, limousine, satu botol Moet et Chandon, satu buket bunga, dekorasi lampu, satu kotak coklat Praline, hadiah.

Selain itu Hotel Mandarin Oriental Jakarta menawarkan satu lagi paket Valentine yang khusus hanya ditawarkan pada tanggal 14 Februari 2011 yaitu, the Suite Valentine. Paket ini termasuk akomodasi seharga Rp. 7.500.00,00 di Oriental Suite atau Rp. 9.500.000,0 di Mandarin Suite, limousine, champagne, buah Strawberry dan coklat Praline pada saat kedatangan, satu buket bunga pada saat kedatangan, paket spa, makan pagi, makan malam. Perayaan Imlek yang juga 
diselenggarakan pada bulan Februari 2011 ditandai dengan pawai 100 lentera yang dibawakan oleh 100 anak-anak dari Yayasan Kampoeng Kids, sebuah yayasan yang membantu pendidikan anak-anak yang kurang beruntung. Pawai dimulai dari depan lobby hotel pada tanggal 13 Februari 2011 pukul 18.00 dipandu oleh tarian barongsai dan akan bergerak ke arah Bunderan Tugu Selamat Datang yang berada tepat di depan hotel. Selain itu MOJKT juga akan memberikan beasiswa bagi siswa berprestasi yang berada dalam asuhan Yayasan Kampoeng Kids. Perayaan ini juga dirayakan di restoran Xin Hwa yang berada dilantai dua. Para tamu dapat menikmati sajian makan malam dengan tiga pilihan set menu dengan harga Rp. 388.000,00 untuk menu dengan 8 jenis sajian, Rp. 588.000,00 untuk 9 jenis sajian dan Rp. 688.000,00 untuk 10 jenis sajian. Ketiga menu perayaan ini termasuk sajian tradisional seperti salad Yee Sang. Penawaran ini berlaku dari tanggal 13-14 Februari 2010.

Selain kegiatan promosi tersebut di atas pihak Communication Department bekerjasama dengan pihak Sales and Marketing Department dimana marketing dari hotel ini mendatangi masingmasing contact person dari perusahaan yang biasa memakai jasa mereka dan juga perusahaan baru yang potensial untuk mereka follow up pada saat menjelang hotel ini akan beroperasi kembali. Dalam analisis situasi ini dapat ditarik kesimpulan bahwa Hotel Mandarin Oriental sudah mempunyai reputasi yang sangat baik di mata publik sehingga dengan mudah mereka dapat menarik tamunya kembali untuk menginap di hotel tersebut. Selain itu mereka juga mendapat tamu baru dari hasil follow up yang mereka lakukan.

\section{Objective}

Tujuan awal Hotel Mandarin Oriental Jakarta adalah memberitahukan kepada publik bahwa hotel ini telah beroperasi kembali karena pada tahun 2007 sampai 2009 mereka memutuskan untuk melakukan renovasi sebagai sebuah pembaharuan yang bertujuan untuk menarik perhatian para tamu dan mempertahankan citranya di tengah persaingan bisnis hotel yang cukup ketat mengingat terdapat tiga hotel sejenis yang berada di lokasi yang berdekatan. Renovasi tersebut mencakup perubahan dalam bentuk interior design lobi hotel dan kamar, perubahan keseluruhan fasilitas hotel Mandarin Oriental Jakarta. Hal ini didukung oleh salah satu narasumber yaitu Ibu Melany J. Matukapan selaku Head of Communication Hotel Mandarin Oriental Jakarta bahwa tujuan dilaksanakannya renovasi adalah untuk memperbarui situasi dan kondisi bangunan termasuk interior yang sudah berusia 29 tahun.

Selama masa renovasi berlangsung pihak Hotel Mandarin Oriental Jakarta tetap membina hubungan baik dengan para tamu. Communications Department selalu memberikan informasi tentang sejauh mana perkembangan selama renovasi berlangsung melalui e-mail. Setelah renovasi selesai dilaksanakan mereka sampai pada tahap re-opening dimana pada tahap ini mereka harus melakukan promosi untuk build awareness bagi publik. Hal ini dilakukan dengan tujuan memberitahukan kepada publik bahwa hotel ini sudah beroperasi kembali.

Pada tahap re-opening ini mereka melakukan beberapa macam langkah promosi seperti: (1) mengirim e-mail kepada tamu yang sebelumnya biasa menggunakan jasa mereka sehingga mereka tahu bahwa hotel ini telah beroperasi kembali; (2) dibantu oleh Sales and Marketing Department mereka datang langsung menemui contact person perusahan-perusahaan atau kedutaan besar yang ada di data base mereka dimana disini tidak saja terdapat tamu lama tetapi juga calon tamu baru untuk pendekatan mereka; (3) memasang iklan di beberapa media cetak baik di Jakarta, ataupun juga di luar negeri seperti Singapura dan Hongkong. Hotel Mandarin Oriental Jakarta mempunyai banyak tamu yang datang dari kedua negara tersebut.

\section{Publics}

Publik adalah sekumpulan orang yang ingin dituju sehingga untuk mencapai tujuan tersebut diperlukan komunikasi. Berkomunikasi dengan publiknya adalah salah satu tugas dari seorang Public 
Relations dimana diantara mereka saling membangun pengertian yang sama satu sama lain. Tugas tersebut dapat dipermudah dengan menentukan siapa publik yang ingin dituju atau dalam hal ini disebut juga target market.

Publik yang dituju oleh MOJKTsendiri adalah kalangan menengah ke atas, lebih spesifik lagi adalah pebisnis. Hal ini didukung oleh pernyataan dari salah satu satu narasumber yaitu Salome Dacey selaku Revenue Manager Hotel Mandarin Oriental Jakarta: Our guests are comes from corporate market companies likes bank, consultant, oil industry, and any different industry and embassy. Pernyataan ini didukung oleh teori dari Wheeled \& Hunger dalam Iriantara (2004) yang mendefinisikan publik sebagai kelompok-kelompok yang berkepentingan dengan aktivitas organisasi, dan lantaran berkepentingan maka kelompok-kelompok tersebut memengaruhi atau dipengaruhi oleh pencapaian tujuan perusahaan. Dalam menjalin komunikasi dengan publiknya ini pihak hotel dibantu oleh hotel groups yang lain di negara dimana perusahaan-perusahaan tersebut berada. Hal ini memang senada dengan yang penulis ungkapkan sebelumnya bahwa hotel ini merupakan sebuah hotel bisnis.

\section{Media}

Media adalah faktor penting bagi Public Relations karena berfungsi sebagai jembatan antara pihak perusahaan dengan publiknya untuk menyampaikan pesan. Pemilihan media yang tepat merupakan salah satu faktor yang penting karena harus disesuaikan dengan target market yang dituju. Hal ini sangat menentukan pandangan publik terhadap positioning perusahaan tersebut.

Dalam mempromosikan masa re-opening media-media yang digunakan oleh Public Relations Hotel Mandarin Oriental Jakarta adalah media cetak baik koran maupun majalah. Seorang Public Relations harus dapat menyampaikan pesannya dengan baik. Dalam Re-Opening Hotel Mandarin Oriental Jakarta, seperti yang terdapat di dalam model komunikasi yang ditulis oleh Effendy, di mana: (1) sender, yaitu pihak hotel yang diwakili oleh Mellany J. Matakupan selaku Head of Communication dan Mardiana Budi selaku Communication Manager; (2) encoding, pemasangan logo Hotel Mandarin Oriental pada iklan-iklan yang ditampilkan di media sehingga mengingatkan publik akan hotel ini; (3) message, pesan yang ingin disampaikan tentang telah beroperasi kembali Hotel Mandarin Oriental Jakarta; (4) media, media yang digunakan adalah media cetak seperti Kompas dan Urban Style. Selain itu digunakan juga media luar negeri seperti di Singapura dan Hongkong, pemilihan kedua negara ini karena banyak tamu yang berasal dari dua negara tersebut; (5) decoding, bagaiman komunikan mengerti pesan yang disampaikan oleh pihak hotel yaitu Communication Department; (6) receiver, publik yang ingin dituju oleh Hotel Mandarin Oriental Jakarta; (7) response, tanggapan yang diterima oleh pihak komunikan setelah disampaikannya pesan, yaitu setelah diedarkannya Press Release; (8) feedback, banyaknya Press Release yang dimuat di media-media; (9) noise, gangguan-gangguan yang tejadi pada saat disebarkannya Press Release, yaitu ketika Press Release tidak dimuat di media-media , yaitu ketika Press Release tidak dimuat di media-media.

Hotel Mandarin Oriental sendiri juga sudah memiliki media-media yang ingin mereka gunakan untuk mendukung program promosi re-opening ini. Seperti yang dikatakan oleh Melany J. Matakupan bahwa: Media yang kami gunakan adalah media cetak baik dalam maupun luar negeri seperti Singapura dan Hongkong, karena dari kedua negara inilah tamu kami paling banyak berasal. Media cetak dalam negeri sendiri seperti Kompas dan Urban Style. Saat ini kami belum menggunakan media elektronik karena masalah biaya yang cukup tinggi. Communication Department sebuah hotel bertaraf internasional tentu sangat berkaitan erat dengan media. Oleh sebab itu mereka harus menjalin hubungan yang baik dengan media: Kami pernah mengadakan acara Sware dimana kami menyediakan tempat untuk makan malam bagi para wartawan dari satu grup media. Pendekatan lain yang kami lakukan lebih bersifat personal misalnya salah satu staff Communication Division kami mengundang salah satu wartawan dari media tertentu untuk makan malam. Hal ini didukung oleh teori dari Lesly dalam Iriantara (2005) yang mengatakan bahwa media relations adalah sebagai berhubugan dengan media komunikasi untuk melakukan publisitas atau merespons kepentingan media terhadap organisasi. 


\section{Budget}

Budget atau anggaran adalah satu hal yang penting dalam suatu perencanaan terutama jika menyangkut sebuah penyelenggaraan acara. Namun penggunaannya juga harus disesuaikan dengan kondisi keuangan dari perusahaan itu sendiri namun dengan tidak mengabaikan tercapainya tujuan dari perencanaan yang ingin dilaksanakan. Dalam perencanaan budget re-opening Hotel Mandarin Oriental Jakarta dapat dioptimalkan di setiap kebutuhan. Untuk penyelenggaraan peresmian pihak hotel tidak dapat menyebutkan berapa biayanya, maka penulis hanya dapat mendeskripsikan perlengkapan yang digunakan pada saat peresmian pembukaan hotel adalah sebagai berikut: undangan (invitations), press kit, photographer, cindera mata (souvenir), sound system, ID card wartawan, sign board, goodie bags, name tag, flowers, food \& beverages, mischellanous. Penggunaan budget yang optimal tetap dapat digunakan dengan tidak mengabaikan hasil yang maksimal sehingga tujuan awal tetap dapat tercapai dan pesan yang ingin disampaikan kepada publik juga dapat diterima dengan baik.

\section{Evaluation}

Langkah keenam dari model perencanaan ini adalah evaluasi hasil dari seluruh kegiatan yang sudah dilaksanakan. Langkah ini diperlukan agar seseorang dapat mengetahui kekurangan, apakah sukses atau tidaknya langkah-langkah kegiatan yang telah dilaksanakan sebelumnya sehingga dapat memperbaikinya di kesempatan yang lain.

Communications Department dari Hotel Mandarin Oriental sendiri selalu melakukakn evaluasi yang biasa dilakukan oleh pihak hotel biasanya satu tahun sekali, namun pada saat interview penulis dengan Communication Manager belum mencapai satu tahun. Hal ini didukung oleh pernyataan Melany J. Matukapan sendiri yaitu: "Biasanya target kami buat per tahun, namun karena sampai saat ini belum satu tahun maka kami belum bisa mengatakan apakah target sudah tercapai atau belum. Sampai saat ini tingkat hunian hotel sudah mencapai $80-90 \%$ dari seluruh kapasitas hunian yang tersedia”. Jika dilihat dari sisi Sales and Marketing seluruh kegiatan yang telah dilakukan dari masa re-opening hingga hotel beroperasi saat ini sudah sangat efektif. Hal ini didukung oleh penyataan dari Salome Dacey bahwa: for re-establishing the hotel nowadays the hotel's guest already 80-90\% fullfil. I think now we're in the right track. Dari pernyataan tersebut dapat disimpulkan bahwa tanggapan dari publik khususnya tamu Hotel Mandarin Oriental Jakarta sangat baik. Hal ini membuktikan bahwa perencanaan yang dijalankan sudah berhasil mencapai target maksimal tamu hotel walaupun belum 100\% kamar penuh.

Untuk mengetahui hasil dari setiap kegiatan dapat dilihat dari dimuatnya Press Release yang diedarkan oleh Communication Department dan juga penyelenggaraan peresmian re-opening Hotel Mandarin Oriental Jakarta. Hal ini menjadi salah satu tolak ukur untuk mengetahui berhasil atau tidaknya sebuah program perencanaan.

\section{PENUTUP}

Setelah melakukan penelitian dengan mengadakan wawancara dengan para narasumber serta menganalisis data penulis menarik beberapa kesimpulan mengenai peran Public Relations dalam mempertahankan citra pada re-opening Hotel Mandarin Oriental Jakarta.

\section{Peran Public Relations}

Peran Public Relations pada saat re-opening Hotel Mandarin Oriental Jakarta sangatlah penting. Mereka adalah jembatan penghubung antara pihak hotel dengan publiknya karena melalui mereka pihak perusahaan dapat menyampaikan pesannya kepada publik. Publik dapat mengetahui 
bahwa hotel ini telah melakukan re-opening melalui upaya yang dilakukan oleh Public Relations seperti penyelenggaraan acara Paket Valentine dan Acara Perayaan Imlek. Selain itu pemasangan iklan di media-media sangat berperan penting untuk promosi hotel ini. Pembuatan Press Release yang kemudian didistribusikan kepada para wartawan berguna sebagai informasi penting yang dapat disampaikan melalui media kepada masyarakat. Media Relations yang selama ini dilakukan dapat membina hubungan baik dengan wartawan sehingga dapat menguntungkan kedua belah pihak. Upayaupaya yang dilakukan di atas adalah usaha untuk membangun brand awareness terhadap publik jika pihak hotel ingin publik mengetahui bahwa hotel ini telah beroperasi kembali.

\section{Saran}

Adapun saran akademis yaitu diharapkan adanya penelitian yang lebih mendalam lagi terhadap peran Public Relations dalam re-opening hotel. Diharapkan juga metode analisis yang berbeda seperti memakai analis data STOPSIT agar mendapatkan hasil yang berbeda. Saran yang dapat diberikan oleh penulis adalah Hotel Mandarin Oriental Jakarta agar lebih meningkatkan kegiatan promosinya terutama dalam pemasangan iklan dengan tidak saja menggunakan media cetak tetapi juga menggunakan media elektronik. Dengan meningkatkan kegiatan promosi pemasangan iklan di media elektronik tersebut diharapkan dapat memaksimalkan kerja Public Relations dalam mencapai tujuan program kerjanya. Selain itu, Hotel Mandarin Oriental Jakarta agar lebih mempromosikan kegiatankegiatan atau acara-acara yang dilaksanakan di hotelnya agar masyarakat lebih aware terhadap Hotel Mandarin Oriental Jakarta sendiri. Dengan publik mengetahui kegiatan-kegiatan yang dilaksanakan di hotel maka nama hotel dapat lebih menempel di benak publik.

\section{DAFTAR PUSTAKA}

Ardianto, E., \& Soemirat, S. (2003). Dasar-dasar public relations. Bandung: Remaja Rosdakarya.

Effendy, O. U. (1999). Ilmu komunikasi: teori dan praktek. Bandung: Remaja Rosdakarya.

Hasan, I. (2002). Metode penelitian dan aplikasinya. Bogor: Ghalia Indonesia.

Jefkins, F., \& Yadin, D. (2004). Public relations. Jakarta: Erlangga.

Kountor, R. (2005). Metode penelitian: untuk penelitian skripsi \& thesis. Jakarta: PPM.

Kusumastuti, F. (2002). Dasar-dasar humas. Jakarta: Ghalia Indonesia.

Menteri Pariwisata Pos dan Telekomunikasi. (2010). Surat Keputusan Menparpostel No. KM 37/PW.340/MPPT-86, tentang Peraturan Usaha dan Penggolongan Hotel, Bab I Pasal 1 Ayat (b).

Moleong, L. J. (2005). Metodologi penelitian kualitatif. Bandung: Rosdakarya.

Mulyana, D. (2007). Ilmu komunikasi: suatu pengantar. Bandung: Remaja Rosdakarya.

Rumanti, M. A. (2002). Dasar-dasar public relations: teori dan praktik. Jakarta: Grasindo.

Ruslan, R. (2003). Manajemen public relations dan media komunikasi: konsepsi dan aplikasi. Jakarta: Raja Grafindo Perkasa.

Ruslan, R. (2004). Metode penelitian PR dan komunikasi. Jakarta: Raja Grafindo. 
Singarimbun, M., \& Sofian, E. (1989). Metode penelitian survei. Jakarta: Pustaka LP3ES Indonesia. Sugiyono. (2007). Memahami penelitian kualitatif. Bandung: Alfabeta.

Sulastiyono, A. (2008). Manajemen penyelenggaraan hotel. Bandung: Alfabeta.

Tjiptono, F. (1996). Manajemen jasa. Yogyakarta: ANDI.

Wiryanto. (2006). Pengantar ilmu komunikasi. Jakarta: Grasindo.

Yoeti, O. A. (2004). Strategi Pemasaran Hotel. Jakarta: Gramedia. 